\title{
Strategic planning from a focus on equity: myth to reality in schools
}

\section{Planificación estratégica desde un enfoque centrado en la equidad: mito a realidad en los centros educativos}

\author{
ÁLVAREZ-CISTERNAS, Marisol del Carmen†**, TORRES-ORELLANA, Brunilda del Rosario and \\ MEDINA-GUAJARDO, Isabel Soledad
}

Universidad Andrés Bello, Chile.

ID $1^{\text {st }}$ Author: Marisol del Carmen, Álvarez-Cisternas / ORC ID: 0000-0002-1418-9524

ID $1^{\text {st }}$ Co-author: Brunilda del Rosario, Torres-Orellana / ORC ID: 0000-0002-9810-462X

ID $2^{\text {nd }}$ Co-author: Isabel Soledad, Medina-Guajardo / ORC ID: 0000-0001-5034-7801

DOI: $10.35429 / J T E R .2021 .19 .7 .8 .16$

Received January 15, 2021; Accepted June 30, 2021

\begin{abstract}
Guidelines related to strategic planning in educational centers are described, particularly in the Arturo Prat Chacón Cadet School (Chile), deepening from an equitycentered approach, starting with the Equity Continuum, this with the purpose of advancing towards strategic planning that promotes actions for a critical transformation in schools. From the methodological point of view, the research is situated, of a qualitative descriptive type, of a non-experimental nature, supported by documentary analysis with an instrumental case study. The research contributed to establishing indicators and descriptors that the educational center leader must consider in a strategic planning and implementation process that truly promotes equity, namely: Fluid and transparent communication with all members of the institution; understanding of the cultural differences that affect the lives and learning of the educational community; immersion in the culture and communities that make up the school; valuing the culture, heritage and experiences of the members that make up the educational community; timely attention to critical institutional nodes, where equity and social justice should be the pillars in the statement of objectives of the school.
\end{abstract}

Education, Strategic planning, Equity

\section{Resumen}

Se describen lineamientos referidos a la planificación estratégica en centros educativos, particularmente en la Escuela Cadete Arturo Prat Chacón (Chile), profundizando desde un enfoque centrado en la equidad, a partir del Equity Continuum, esto con el propósito de avanzar hacia una planificación estratégica que promueva acciones para una transformación crítica en las escuelas. Desde lo metodológico, la investigación es situada, de tipo cualitativa descriptiva, de corte no experimental, sustentada en análisis documental con estudio instrumental de caso. La investigación contribuyó a establecer indicadores y descriptores que el líder del centro educativo debe considerar en un proceso de planificación e implementación estratégica que promueva verdaderamente la equidad, a saber: Comunicación fluida y transparente con todos los miembros de la institución; comprensión de las diferencias culturales que afectan las vidas y el aprendizaje de la comunidad educativa; inmersión en la cultura y las comunidades que conforman la escuela; valoración de la cultura, el patrimonio y las experiencias de los miembros que conforman la comunidad educativa; atención oportuna de los nudos críticos institucionales, donde la equidad y justicia social deben ser los pilares en la declaración de objetivos de la escuela.

Educación, Planificación estratégica, Equidad

Citation: ÁLVAREZ-CISTERNAS, Marisol del Carmen, TORRES-ORELLANA, Brunilda del Rosario and MEDINAGUAJARDO, Isabel Soledad. Emotional competences relationship and academic performance in university students. Journal of Teaching and Educational Research. 2021. 7-19:8-16.

\footnotetext{
* Correspondence to the Author (Email: marisol.alvarez.cis@gmail.com)

$\dagger$ Researcher contributing as first author.
} 


\section{Introduction}

The strategic planning (SP) process can be as important to an organisation as the results. Strategic planning can be a particularly valuable process when it involves all levels of responsibility and all levels of staff in thinking about how their activities and responsibilities contribute to and impact the institution.

Organisations improve when, starting from an analysis of a present reality, they are able to visualise a possible future reality. Planning, developed collectively, allows the visualisation and achievement of the dreams of a community, for which it is necessary to address some criteria: relevance, efficiency, effectiveness, impact and sustainability. (Jaurlaritza, 2010).

However, when this PE is based on an approach based on equity, particularly in the promotion of actions for a critical transformation in schools, the issue becomes more complex, and it is worth asking ourselves whether it will be a myth or a reality, since it is not a myth or a reality: Myth or reality, since it involves not only a specific group within the school, but the entire educational community with its experiences, dreams, challenges, fears, backgrounds, with a social and cultural capital that is often lacking, which undoubtedly produces a paradigmatic break from what we have naturalised as valid, which is a PE process that caters more to instrumental aspects.

Thus, this article, in addition to addressing some theoretical and practical references of the PE process, delves into an approach focused on equity in schools, taking the Arturo Prat Chacón Cadet School as a case study, based on the principles formulated in the Equity Continuum (Murray, 2011).

\section{Development of the topic}

SP is an organisational management activity used to set priorities, focus energy and resources, strengthen operations, ensure that employees and other stakeholders are working towards common goals, establish agreement on expected results, and evaluate and adjust the organisation.
According to Chiavenato (2010), cited by Ulloa (2019), SP is the process of "formulating strategies and implementing them through tactical and operational plans" (p. 44). For Manes (2005) and Bolivar (2010), SP is a process that establishes the opportunities and threats of the external context as well as the strengths and weaknesses of the internal context, articulating a vision, mission, goals and institutional objectives in line with the educational expectations of the community, to propose and develop strategies, within the framework of an action plan, to guide the institutional work, while for Navajo (2009), it is supported as "a tool for diagnosis, analysis, reflection and decision making, about the current work and the path to be followed in the future by the communities" (p.21). (Ulloa, 2019)

Thus, according to Chiavenato (2010) the main characteristics of an SP process are:

It is systemic: It involves looking at the organisation as a whole, i.e. a system.

- It focuses on the future: It involves building a long-term image or vision of the organisation.

It creates value: Strategic planning not only considers stakeholders, but also creates value for parents, teachers, students and local authorities.

- It is participatory: It considers the effective inclusion of all stakeholders, especially those it will affect.

It must have continuity: It implies developing the process on an ongoing basis, at strategic, tactical and operational levels.

- It needs to be implemented: The main challenge is its implementation, through the involvement of all stakeholders it affects.

It needs to be monitored: The expected results, both during the process and at the end of the period, need to be systematically evaluated. (Ulloa, 2019) 
In addition to the above, based on Pozner's (2003) approaches, an EP process requires implementation and management, providing school actors with theoreticalpractical approaches or tools such as possibilities for self-management, planning and evaluation, in order to carry out actions aimed at improving and transforming the reality and its school context, particularly the teachinglearning processes. In addition, Gajardo and Ulloa (2016), together with Gajardo (2019), formalise some qualities and attributes of a strategic planning process for educational centres, where the focus is on the people, their students, their families and the collective that makes up the institution itself. In this way, some of their considerations:

Systemic and strategic intervention: This involves visualising the educational situation, developing the strategy and articulating actions to achieve the objectives and goals that are set; making planning a tool for self-regulation and governance, to enhance the capacities of all for meaningful intervention.

Organisational cultures united by a vision of the future: Suggests the creation of multiple scenarios for different situations, based on clear objectives and high-level consensus to reach higher stages as an institution; where the actors promote an intelligent organisation, rich in proposals and creativity that stimulate participation, responsibility and shared commitment.

Advice and guidance for professionalisation: Existence of spaces for reflection for lifelong learning, to think about thinking, rethink action, expand the epistemic power and voice of teachers; it is about enabling circuits to identify areas of opportunity and to generate networks for the exchange of experiences in a professional development plan.

Reconfiguration, new competences and professionalisation: This implies the need for the various educational actors to possess the indispensable elements for understanding new processes, opportunities and solutions to the diversity of situations.
- Teamwork: This provides the school institution with a shared vision of where it wants to go and what educational concepts and principles it intends to promote. It also has to do with processes that facilitate understanding, planning, action and joint reflection on what is to be done and how, which, to be effective, must be developed in a collegial manner.

- Openness to learning and innovation: This is based on the ability of teachers to find and implement new ideas for the achievement of their educational objectives, as well as to break down inertia and barriers, favouring the definition of goals and prioritising integral transformation. Organisations open to learning are able to systematically address and resolve adverse situations, generate new approaches, learn from their own and others' experience, and generate knowledge and transfer it to their practices.

Pedagogical centrality: Based on the idea that schools are the key organisational unit of education systems, it consists of generating learning for all students.

Similarly, Pérez-Ruiz, A. (2014), emphasises the need for flexibility in educational centres, which implies permeability to deal with changes in a dynamic environment that is not exempt from unforeseen events, both internal and external to the institution itself; this need for adaptation, where all actors are committed and involved, since they are considered and given the space to give their opinion and contribute to decisionmaking, is the closest thing to what Senge (1990) would call smart organisations.

Bravo, Castro and Rojas (2017) propose the existence of three formally established stages in a PE process, beginning with the Philosophical Stage, in which the institutional principles, vision and mission are analysed. To do this, it is necessary to review the principles, values and identity hallmarks established on the basis of the Institutional Educational Project (PEI). 
In this way, the school's principles are initially formalised in a matrix that makes it possible to explain the most significant principles that give the school its identity. In this way, the principles that make up the matrix are values that identify and differentiate the school and, in the same way, constitute the guidelines for the school's values and formative education. Together with the above, the vision is relevant as it establishes where the institution is heading, the desired future, the aspirations of the institution and how it wants to be recognised. The mission, on the other hand, refers to how we are going to achieve the ideal established in the vision, hence both must be coherent, being very important for an organisation because it synthesises and makes explicit the general idea that links the practical strategies, allowing the management team and the community to align and articulate their actions and decisions with a clearly established vision and mission.

The second phase of the SP process corresponds to the Analytical Stage, which is characterised by an Institutional Diagnosis, within a situational framework. In this way, this diagnosis is implemented from the internal and external analysis of the institution, based on a set of areas that make up the School Management Model, establishing from here the strengths, weaknesses, opportunities and threats (SWOT) of the institution. From the analysis of the information collected in the SWOT, the needs of the school and the critical issues are established, those aspects that need to be addressed immediately, in the short term, as well as those aspects that can be addressed in the medium and long term, which make up a set of needs, and also consolidate and safeguard the positive aspects of the institution. In order to meet these needs, it is necessary to establish and deploy a set of strategies, which can be operationalised through strategic objectives that, in their wording, must consider a time circumstance and a standard of measurement.

In this way, and after establishing a set of strategies to address the needs detected and prioritised within a time scenario, the third stage of the SP begins, which is the Operational Stage, where, based on the strategies, a set of strategic objectives are formalised, which must be measurable. These objectives are concretised through action plans that set measurable goals, specific objectives and concrete activities.
Measurable objectives are important for an organisation because they allow progress to be assessed and areas for improvement to be addressed in a timely manner.

However, SP as a process is nothing more than a plan that systematises the objectives in an educational institution. It is a document that shows the strategies and pathways for their achievement and describes in detail the corresponding evaluation systems. Thus, the strategic plan represents a very effective and useful management tool for working with a view to the future. In order to do so, it is vital to collect and process information about the current situation. Knowing where we stand allows us to contextualise the starting point from which medium-term objectives and strategies can be set. (Gallardo, 2014).

Approaching a PE process from an equityfocused approach, as stated by Wagoner, (2018), involves referring to some principles of culturally relevant pedagogy, which emphasises the building of healthy and authentic relationships in the school community and in the classroom. Teachers need to know and feel that their school principal cares and empathises with them, while students need to know and feel that their teachers care and understand them. Both teachers and students are more engaged and respond more positively when they believe and perceive that their superiors genuinely care about them, or where power is focused, demonstrating care, providing a relevant and effective learning environment. Teachers' knowledge of the cultural diversity of the school, including the integration of ethnically and culturally relevant content in the curriculum, as well as in the assessment of learning, and the delivery of lessons in a supportive manner, are imperative for students' academic success, and this would be a scenario that promotes social justice in schools.

Alongside the above, applying the guidelines and work of Ontario Canada's Ministry of Education's Ministry of Equity and Inclusive Education to move towards equity-based education, the work of the Centre for Urban Teaching (CUS) and the Faculty of Education at the University of Toronto (OISE), which jointly created the Framework for Culturally Responsive and Relevant Pedagogy (CRRP), to promote critical awareness and questioning of the situation in educational institutions, is evident. 
The Equity Continuum (Murray, 2011), understood as a continuum of equity, promotes actions for critical transformation in schools and classrooms, proposes and operationalises a framework covering seven areas of equitable practices in schools, namely: a) Classroom Climate and Instruction, b) School Climate, c) Student Voice and Space, d) School Family/Guardian Relations, e) School Leadership, f) Community Connections, and g) Culture of Professional Development. These seven areas ask key questions regarding the thinking and practice of equity, transforming the Continnum into an instrument that allows for monitoring and establishing progress from the schools themselves.

However, in order for educational institutions to move towards culturally responsive and relevant schools, they need to consider in their $\mathrm{PE}$ and implementation processes:

Understanding cultural differences that affect teachers' and students' lives and learning. This implies understanding how differences in race, background, socioeconomic status, schooling, family configuration, among others, can affect coexistence, teaching and learning, as well as the building of trusting relationships.

Knowing the environment, the place where teachers, students and the community live, establishing the potential and strengths of these communities, this immersion implies cultural sensitivity.

-Valuing the culture, heritage and experiences of the members of the educational community. This implies moving towards a more situated and contextualised, culturally inclusive curriculum, which involves highlighting the culture of the members of the educational community and involving them in the institution's own work.

\section{Methodology}

The study was based on an interpretative paradigm with a qualitative methodological approach, descriptive and non-experimental design based on documentary analysis with an instrumental case study Stake (2007).
In effect, methodologically, the description and analysis of the PE of the Arturo Prat Chacón Cadet School was deepened, applying the guidelines and the work of the Ministry of Education of Equity and Inclusive Education, Ontario Canada, to move towards an education based on equity. This highlights the work of the Centre for Urban Teaching (CUS) and the Faculty of Education at the University of Toronto (OISE), which jointly created the Framework for Culturally Responsive and Relevant Pedagogy (CRRP), addressing the promotion of critical awareness and questioning of the situation in educational institutions. For the purposes of data collection, and in order to investigate and understand the concepts and networks of meanings that the directors of the Arturo Prat Chacón Cadet School perceive with respect to the designed and implemented PE, guidelines are applied from the equity-focused approach. For this purpose, a sample of six managers was selected, who voluntarily expressed their willingness to participate in the research, with prior ethical consent. In each case, six questions corresponding to the area of school leadership of equitable practices in schools were sent by personal e-mails, with the aim of generating descriptive categories and units of meaning based on their perceptions, and they had one week to respond and send their contributions by the same means.

Of the questions formulated on the basis of a set of indicators, the following should be noted:

1.- Does the head teacher and his or her school management team communicate their strategic development plan and work plan (visions) clearly to the whole community?

2.- Does the strategic planning and work plans articulate the notion that equity and social justice issues are the pillars of the school's mission statement?

3.- Is leadership in the school shared by all stakeholders in different ways?

4.- Is there power sharing and participation in decision-making in the school?

5.- Does the school have systematic policies and practices in place that help to build and sustain leadership throughout the school? 
Are school staff supported and encouraged to develop and provide leadership in different areas?

Subsequently, and after receiving input from the principals, the principals were convened for a meeting using the zoom meeting platform. The qualitative information was transcribed in textual form, the analysis was carried out from an inductive approach, through the constant method of comparison Glaser and Strauss (1967), using the qualitative analysis software Atlas $\mathrm{T}$, following the proposal of Huberman and Miles (1994), safeguarding the criteria of credibility, transferability and confirmability.

\section{Resultados y discusión}

Based on the qualitative analysis carried out, it was possible to deepen the knowledge and understanding of the managers interviewed. This resulted in three descriptive categories of analysis and 41 units of meaning relevant to the managers interviewed, as illustrated in Table 1.

\begin{tabular}{|l|r|}
\hline Descriptive categories & $\begin{array}{c}\text { Number of meaning } \\
\text { units }\end{array}$ \\
\hline $\begin{array}{l}\text { Management and strategic } \\
\text { planning }\end{array}$ & 14 \\
\hline $\begin{array}{l}\text { Leadership and decision- } \\
\text { making }\end{array}$ & 15 \\
\hline Participation & 12 \\
\hline
\end{tabular}

Table 1 Categorisation and units of meaning relevant to managers

Source: Own elaboration

In order to look for similarities in content, structure and theory. From the descriptive categories, two meta-categories were formed, as illustrated in table 2 .

\begin{tabular}{|l|l|l|}
\hline Meta-categories & \multicolumn{1}{|c|}{ Coding } & \multicolumn{1}{c|}{ Definition } \\
\hline Strengths & FOR & $\begin{array}{l}\text { Description of the } \\
\text { aspects that } \\
\text { promote equity in } \\
\text { a strategic } \\
\text { planning and } \\
\text { management } \\
\text { process. }\end{array}$ \\
\hline Critical nodes & ND & $\begin{array}{l}\text { Description of the } \\
\text { aspects that } \\
\text { require further } \\
\text { development as } \\
\text { they are critical } \\
\text { nodes for the } \\
\text { school from an } \\
\text { equity-based } \\
\text { approach. }\end{array}$ \\
\hline & &
\end{tabular}

Table 2 Meta-categories, codes and definitions

Source: Own elaboration

ISSN-2444-4952

ECORFAN $^{\circledR}$ All rights reserved.
Based on the meta-categories, which consider three qualitative domains, the teachers' opinions were grouped together, and some of the opinions are transcribed in Table III for illustrative purposes.

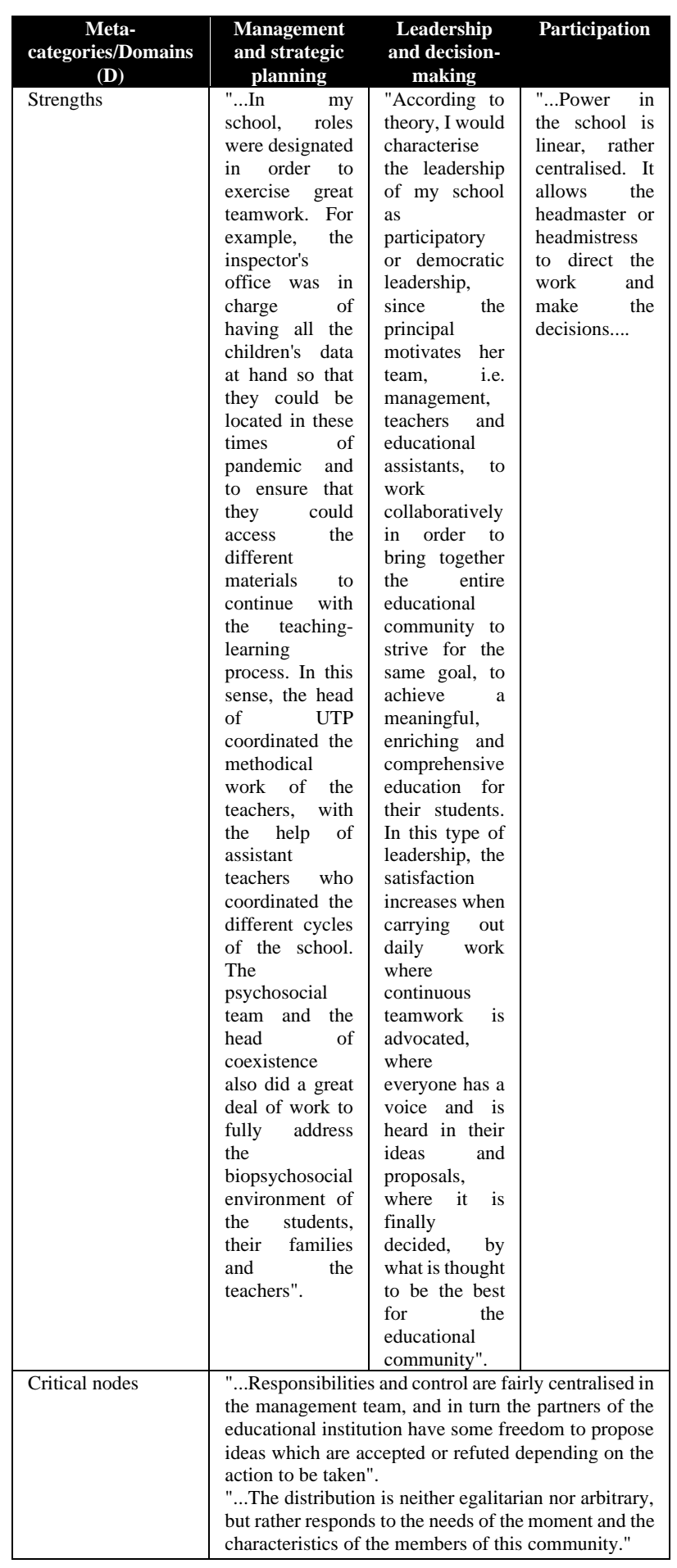

Table 3 Meta-categories and qualitative domains Source: Own elaboration

In addition to the above, as illustrated in figure I, the semantic network is presented, based on the three descriptive categories that arise from the analysis carried out using Atlas T.

ÁLVAREZ-CISTERNAS, Marisol del Carmen, TORRESORELLANA, Brunilda del Rosario and MEDINA-GUAJARDO, Isabel Soledad. Emotional competences relationship and academic performance in university students. Journal of Teaching and Educational Research. 2021 


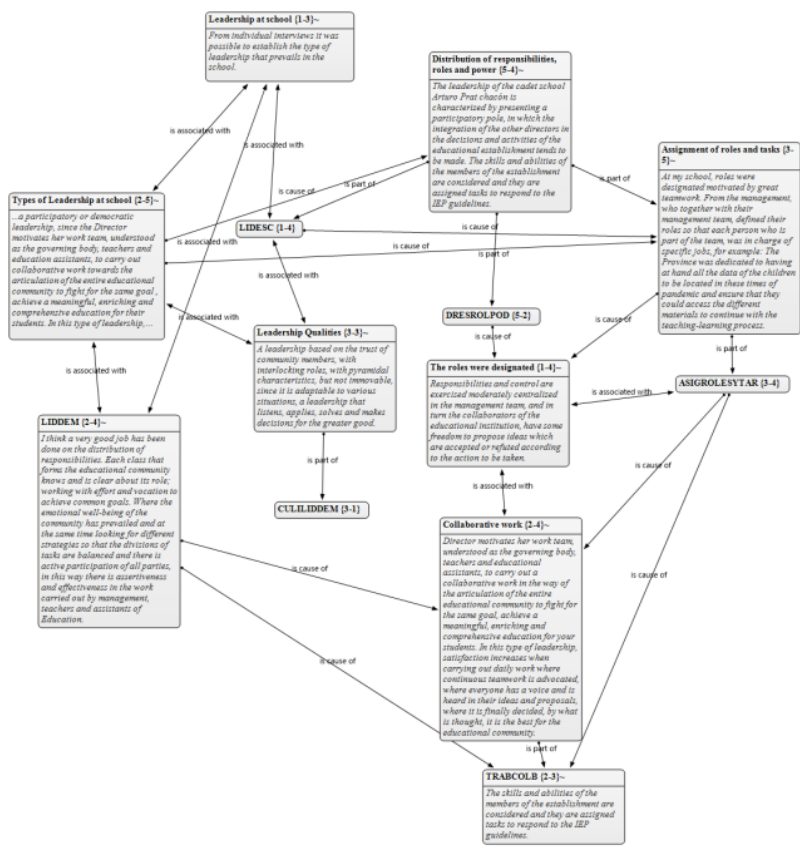

Figure 1 Semantic network of descriptive categories Source: Own elaboration

The results obtained confirm the findings of Sans-Martín et al. (2016), since in the school, distributive leadership predominates over instructional leadership, which is in line with a strategic planning process based on equity. This type of leadership predominant in the school, also called democratic, situational, co-leadership (Spinel, 2006), or nominated collaborative, emergent, new leadership (Bolden, 2011), is reaffirmed by Villa (2013). This has had a positive influence on the collaborative work between the various actors that make up the school and is recognised as such, confirming Bolívar (2019), who highlights the positive and direct effects of the type of leadership, particularly the collaboration and joint work between teachers, which had a positive impact on the pedagogical practice of the school. Similarly, it is evident that although the management team had been working from a leadership that could be close to democratic, it is confirmed that this is on the way to consolidation, since the school was able to adapt quickly to a crisis situation such as the pandemic, since there were institutional and management conditions, thus confirming the statements of Ahumada et al. (2017), regarding the practice of distributive leadership, and the timely allocation of roles and tasks, thereby promoting the improvement of the school.
All in all, the school's strategic planning and work plans articulate the notion that equity and social justice issues are the pillars of the school's mission statement. Indeed, the school has a high percentage of immigrant students, so they have made an effort to make these cultures visible, through immersion in the culture and communities that make up the school; valuing the culture, heritage and experiences of the members that make up the educational community. However, it is recognised that these are still incipient approaches, in addition to the curricular and evaluative spheres, among others.

Likewise, the findings of this study confirm Wagoner's (2019) statements on the need to build healthy and authentic relationships in the school community and in the classroom, which is consistent with equitable management and PE processes in schools. As well as Aziz (2018), who states that all members of the educational community need to know and feel that the principal of their school genuinely cares and empathises with them, an issue that is confirmed in this study, from a participatory strategic planning process, promoting leadership in other members of the community, even though it is recognised that it is incipient.

\section{Conclusions}

PE from an equity-based approach will not be just a myth and makes sense in schools when it is designed and implemented based on the multicultural diversity of schools. This is an issue that is confirmed in the school under study, considering social and cultural capital, and including ethnic, culturally diverse and representative content in the training curricula, recognising that although there is progress, these are still incipient processes. Management teams will be effective when they give clear signals that the educational community and each of its members matter to them, focusing on building healthy, harmonious and genuine relationships with teachers, students, families and the school community. (Figueroa, Valenzuela \& Vanni, 2019). In this sense, and particularly in Chile, the results of this research allow sensitivity about a style of strategic planning based on equity and social justice, where the participation of the various groups that make up the school is promoted. 
In this way, from an approach based on equitable practices in schools focused on the area of school leadership (Murray, 2011) and the strategic planning processes of the case study, some indicators and descriptors are revealed as illustrated in Table 4.

\begin{tabular}{|c|c|}
\hline Indicators & Descriptors \\
\hline \multirow[t]{2}{*}{$\begin{array}{l}\text { The principal and his } \\
\text { or her school } \\
\text { management team } \\
\text { communicate their } \\
\text { strategic development } \\
\text { plan and work plan } \\
\text { (visions) clearly to the } \\
\text { whole community. }\end{array}$} & $\begin{array}{l}\text { - School announcements are } \\
\text { used as a means to } \\
\text { reinforce the school's } \\
\text { focus. }\end{array}$ \\
\hline & $\begin{array}{l}\text { - The school's mission } \\
\text { statement and vision are } \\
\text { visible to all stakeholders } \\
\text { (e.g. postings in } \\
\text { classrooms, hallways, } \\
\text { school office, community } \\
\text { bulletin board, and school } \\
\text { website). }\end{array}$ \\
\hline $\begin{array}{l}\text { The strategic planning } \\
\text { and work plans } \\
\text { articulate the notion } \\
\text { that equity and social } \\
\text { justice issues are the } \\
\text { pillars of the school's } \\
\text { mission statement. }\end{array}$ & $\begin{array}{l}\text { - Opportunities are provided } \\
\text { for ongoing reviews and } \\
\text { feedback of the mission } \\
\text { statement and transparency } \\
\text { of its active use in the } \\
\text { school (e.g. articulation of } \\
\text { student achievement and } \\
\text { other goals within the } \\
\text { school community are } \\
\text { highlighted through } \\
\text { newsletters, school board } \\
\text { agendas, and school } \\
\text { websites). }\end{array}$ \\
\hline $\begin{array}{l}\text { Leadership in the } \\
\text { school is shared by all } \\
\text { participants } \\
\text { different ways. }\end{array}$ & $\begin{array}{l}\text { - Leadership teams include } \\
\text { teachers in a variety of } \\
\text { roles. }\end{array}$ \\
\hline
\end{tabular}

Table 4 Indicators and descriptors of school leadership in schools that promote equity

Source: Own elaboration

In this way, they show the need to incorporate elements associated with equity and social justice in the SP components, explicitly and disseminated throughout the community, as well as to move towards shared leadership and the distribution of power, involving the different strata in leadership roles and decision-making, recognising best practices, recognising the other as an authentic other, and promoting the participation of the entire community.

\section{References}

Ahumada, L., González, A., Pino, M. Maureira, O. (2017), Liderazgo distribuido en establecimientos educacionales: recurso clave para el mejoramiento escolar. Informe Técnico $N^{\circ} 7$, Santiago de Chile, Líderes EducativosCentro de Liderazgo para la Mejora Escolar.

Aziz, C. (2018). Gestión del cambio, creencias y teoría de acción para la mejora escolar. Nota Técnica $\mathrm{N}^{\mathrm{o}}$ 3. LIDERES EDUCATIVOS, Centro de Liderazgo para la Mejora Escolar: Chile. Recovered in: https://www.lidereseducativos.cl/recursos/gesti on-del-cambiocreencias-y-teoria-de-accion/

Bravo, M; Castro L.; Rojas, A. (2017). Manual de Planificación estratégica: una HerraMienta Para la gestión. Educrea. Recovered in: https://educrea.cl/wp-

content/uploads/2017/05/DOC1-manualplanificacion.pdf

\section{Bolden, Richard (2011), “Distributed Leadership}

in Organizations: A review of theory and research", International Journal of Management Reviews, vol. 13, num. 3, pp. 251 269.

Bolívar, A. (2019). Una dirección escolar con capacidad de liderazgo pedagógico, Madrid, La Muralla.

Bolivar, A. (2010). Liderazgo para el aprendizaje. Organización y Gestión Educativa, (1), 15-20.

Chiavenato, I. (2010). Planeación estratégica: Fundamentos y aplicaciones. McGrau HillI Interamericana editores S.A, México.

Figueroa, D., Valenzuela, J.P. y Vanni, X. (2019). Coherencia entre los distintos marcos regulatorios y políticas hacia los líderes escolares. Nota Técnica $\mathrm{N}^{\mathrm{o}}$ 5. Líderes Educativos, Centro de Liderazgo para la Mejora Escolar: Valparaíso, Chile. Recovered in: https://www.lidereseducativos.cl/recursos/coher encia-entre-los-distintos-marcos-regulatoriosypoliticas-hacia-los-lideres-escolares/ 
Gajardo, J. (2019). Analizando la visión de aprendizaje presente en el establecimiento desde un enfoque de Aprendizaje Profundo. Nota Técnica $\mathrm{N}^{\mathrm{o}}$ 6. Líderes Educativos, Centro de Liderazgo para la Mejora Escolar: Valparaíso, Chile. Recovered in: https://www.lidereseducativos.cl/recursos/anali zando-la-vision-de-aprendizaje-presente-enelestablecimiento-desde-un-enfoque-deaprendizaje-profundo/

Gajardo, J. y Ulloa J. (2016). Liderazgo pedagógico, conceptos $\mathrm{y}$ tensiones. Nota Técnica $\mathrm{N}^{\circ} 6$, Líderes Educativos, Centro de Liderazgo para la Mejora Escolar: Universidad de Concepción, Chile. Recovered in: https://www.lidereseducativos.cl/recursos/lidera zgo-pedagogico-conceptos-y-tensiones/

Gallardo, R. (2014). Planificación estratégica en educación: retos y oportunidades. Departament d'Educació de la Generalitat de Catalunya. España. Recovered in: https://ined21.com/p7216/

Glaser B, Strauss A. (1967). The discovery of grounded theory: Strategies for qualitative research. New York: Aldine Publishing Company; p.101-15.

Huberman A, Miles M. (1994). Data management and analysis methods. En: Denzin N, Lincon Y, editores. Handbook of Qualitative Research. Thousand Oaks, California: Editorial Sage; p. 428-44.

Jaurlaritza, E. (2010). La planificación en el marco escolar. Gobierno Vasco Depertamento de educación, Universidd e Investigación. España.

Manes, J. (2005). Gestión estratégica para instituciones educativas. Guía para planificar estrategias de gerenciamiento institucional. Granica, Buenos Aires.

Murray, K. (2011). Equity Continuum: Action for Critical Transformation in Schools and Classrooms. Ontario Institute for Studies in Education, Centre for Urban Schooling Staff, Ontario Institute for Studies in Education. Centre for Urban Schooling A Different Publisher.ISBN 0981188540, 9780981188546.

Navajo, P. (2009). Planificación estratégica en instituciones no lucrativas. Narcea SA. Madrid, España.
Pérez-Ruiz, A. (2014). Enfoques de la gestión escolar: una aproximación desde el contexto latinoamericano, en Educación y Educadores, vol. 17, núm. 2, pp. 357-369.

Pozner, P. (2003). La gestión escolar. Secretaría de Educación Pública (sep). Antología de gestión escolar. México.

Sans-Martín, A., Guardia, J. y Triadó-Ivern, X. (2016), "El liderazgo educativo en Europa: una aproximación transcultural", Revista de Educación, núm. 371, pp. 83-99.

Stake, R. (2007). Investigación con estudio de casos. Segunda edición. Ediciones Morata S.L. Madrid.

Senge, P. (2012). La quinta disciplina. El arte y la práctica abierta al aprendizaje. Granica.

Ulloa, J. (2018). Análisis y formulación estratégica de la mejora educativa: Conceptos, tensiones y desafíos. Informe Técnico $\mathrm{N}^{\mathrm{o}} 5$. LIDERES EDUCATIVOS, Centro de Liderazgo para la Mejora Escolar: Chile.

Spillane, J. (2006). Distributed Leadership, San Francisco, Jossey-Bass.

Villa, A. (2013), "Competencias de liderazgo en equipos directivos", en Aurelio Villa (ed.),

Liderazgo pedagógico en los centros educativos: competencias de equipos directivos, profesorado y orientadores: VI Congreso Internacional sobre Dirección de Centros Educativos, Bilbao, Editorial Mensajero, pp. 329-366.

Wagoner, J. (2019). Tres principios para le pedagogía culturalmente relevante. Universidad de Portland. Recovered in: http://otrasvoceseneducacion.org/archivos/2905 93

Recovered in: http://otrasvoceseneducacion.org/archivos/tag/p edagogia-culturalmente-relevante
ÁLVAREZ-CISTERNAS, Marisol del Carmen, TORRESORELLANA, Brunilda del Rosario and MEDINA-GUAJARDO, Isabel Soledad. Emotional competences relationship and academic performance in university students. Journal of Teaching and Educational Research. 2021 